\title{
Influence of Glomus intraradices on Black Foot Disease Caused by Cylindrocarpon macrodidymum on Vitis rupestris Under Controlled Conditions
}

\author{
Elsa Petit and Walter Douglas Gubler, Department of Plant Pathology, University of California, Davis 95616
}

\begin{abstract}
Petit, E., and Gubler, W. D. 2006. Influence of Glomus intraradices on black foot disease caused by Cylindrocarpon macrodidymum on Vitis rupestris under controlled conditions. Plant Dis. 90:1481-1484.

We examined the influence of an arbuscular-mycorrhizal fungus, Glomus intraradices (INVAM CA 501), on black foot disease caused by the fungus Cylindrocarpon macrodidymum on Vitis rupestris $\mathrm{cv}$. St. George under controlled conditions. Mycorrhizal or nonmycorrhizal grape rootings were inoculated with the pathogen. Eight months following inoculation with the pathogen, we evaluated disease severity, vine growth, and mycorrhizal colonization. Mycorrhizal plants developed significantly less leaf and root symptoms than nonmycorrhizal plants $(P=0.04$ and $P$ $<0.0001$, respectively). Only nonmycorrhizal grape rootings inoculated with the pathogen had significantly less dry root and leaf weights compared with the noninoculated control $(P=0.0021$ and $P=0.0017$, respectively). Mycorrhizal colonization was high $(48.3 \%$ for the noninfected control and $54.5 \%$ for plants infected with C. macrodidymum) and not significantly affected by inoculation with $C$. macrodidymum $(P=0.2256)$. Thus, $V$. rupestris preinoculated with $G$. intraradices were less susceptible to black foot disease than nonmycorrhizal plants. Results from this study suggest that preplant applications of $G$. intraradices may help prevent black foot disease in the nursery and in the vineyard.
\end{abstract}

Additional keywords: endomycorrhizal symbiosis, glomalean fungi, replant disease, vesiculararbuscular mycorrhizae, Vitis vinifera

Cylindrocarpon macrodidymum Schroers, Halleen, \& Crous is a recently described fungus causing black foot disease, a root and crown rot of grape rootings (Vitis spp.) (20,32). Young vines, up to 8 years old, are primarily affected by the disease (27). Because diseased plants must be removed, the disease causes substantial economic losses due to replanting costs and loss of production. First reported in France in 1961 (27), the disease occurs in all major viticulture regions throughout the world, including Italy $(16,17)$, Portugal (36), Spain (1), South Africa (20), New Zealand (20), and Australia (44). Black foot disease became a problem in vineyard establishment in California in the 1990s (37).

Although the disease cycle of Cylindrocarpon spp. on grapevine is unknown, its behavior and effects have been well studied on other hosts $(4,5)$. Cylindrocarpon infects roots through natural openings or wounds $(4,5)$. Over time, the fungus pro-

Corresponding author: W. D. Gubler

E-mail: wdgubler@ucdavis.edu

Accepted for publication 22 May 2006.

DOI: 10.1094/PD-90-1481

(C) 2006 The American Phytopathological Society duces black, sunken, necrotic root lesions and invades lignified tissues of the plant (38). In cross section, the base of the trunk appears necrotic and xylem vessels are plugged with black inclusions and tyloses (38). Reduced mineral and water uptake results in plant dieback. Cylindrocarpon produces slimy spores disseminated in water (5) as well as resistant chlamydospores, which allow the pathogen to survive in the soil. There is evidence that the pathogen is introduced to vineyards via contaminated nursery stock (19), but the presence of the pathogen in vineyards is known to be an important source of inoculum (18). Because the primary source of inoculum is in the soil and infection is through the roots, it is critical to find ways to protect the roots.

Although control of Cylindrocarpon spp. by preplant fumigation with methyl bromide has been successful (47), the use of this soil fumigant is being phased out in the United States. Alternatives to methyl bromide are therefore needed, but fungicides effective against Cylindrocarpon spp. are not registered and host resistance is lacking (E. Petit and W. D. Gubler, unpublished). Instead, biological control, including the use of arbuscular-mycorrhizal (AM) fungi, is being pursued. Mycorrhizal fungi have been shown to help prevent root rot caused by Cylindrocarpon spp. on pine
(6) and strawberry (31). The AM fungus, Glomus aggregatum Schenck \& Smith emend. Koske, prevented root rot caused by $C$. destructans (Zinssm.) Scholten on peach rootstocks (46).

In the field, grapevines are naturally colonized by AM fungi $(8,11,23,33,41)$. Under P-deficient soil, Vitis vinifera cultivars and common Vitis rootstocks are highly responsive to AM colonization (26). Soil fumigation, however, kills these endemic AM fungi (8). In these fumigated, P-deficient soils, vines are weaker due to the absence of AM fungi (29). AM fungi enhance plant resistance to abiotic or biotic stresses $(22,40,45)$. The severity of abiotic stresses including inadequate nutrition and/or water and/or aeration and/or soil structure has been positively correlated with pathogenicity of $C$. macrodidymum $(27,37)$. In California, black foot disease is exacerbated by heavy or poorly drained soils and/or poor planting practices and/or early fruiting (37). In France, the main factors associated with black foot disease are excessive soil compaction and subsequent water drainage problems (27). By enhancing plant resistance to these stresses, AM fungi may decrease grape rooting susceptibility to black foot. Artificially inoculating AM fungi at planting and in their first years of establishment may protect grape rootings against black foot disease because disease susceptibility decreases as a grapevine ages.

This study was initiated to determine whether root colonization by an AM fungus, $G$. intraradices, influences the susceptibility of grape rootings to $C$. macrodidymum.

\section{MATERIALS AND METHODS}

Preparation of mycorrhizal inoculum, mycorrhizal spore extraction, and evaluation of mycorrhizal colonization. Sudan grass (Sorghum vulgare Pers.) seeds were surface-sterilized in a $10 \%$ sodium hypochlorite solution for $10 \mathrm{~min}$ and sown in a mixture of twice autoclaved pro-mix BX (Premier Horticulture, Oceanside, CA) and quartz sand (1:2, vol/vol). G. intraradices (INVAM CA501) was added to the mixture at planting in the form of spores and infected chopped roots of Sudan grass. Sudan grass seedlings were grown under controlled conditions $\left(25^{\circ} \mathrm{C}, 60 \%\right.$ humidity, 12-h photoperiod), watered three times 
per week, and fertilized weekly with a modified Hoagland's solution (21) at 0.25strength P. Four months after inoculation with mycorrhizae, Sudan grass roots and soil were dried for a week. Then dry roots were chopped and stored with the dry soil in sealed plastic bags at $5^{\circ} \mathrm{C}$ until needed as inoculum on grape cuttings. Nonmycorrhizal Sudan grass roots were used as a control to account for increase in organic matter contributed by roots.

A representative sample of each root system was kept for estimation of mycorrhizal colonization by clearing and staining with trypan blue. Root samples were rinsed of soil and debris and stored in a $50 \%$ ethanol solution. Before clearing and staining the roots, the ethanol solution was removed and each root sample was placed in a Biopsy cassette (Fisher Scientific International, Santa Clara, CA). Roots were cleared and stained using the protocol by Koske and Gemma (24): cleared in 3\% (wt/vol) $\mathrm{KOH}$ at $90^{\circ} \mathrm{C}$ for $60 \mathrm{~min}$, then rinsed in three changes of water, cleared in $\mathrm{H}_{2} \mathrm{O}_{2}$ containing $2 \% \mathrm{NH}_{4} \mathrm{OH}$ at $90^{\circ} \mathrm{C}$ for $20 \mathrm{~min}$, rinsed in running water, acidified in $1 \% \mathrm{HCl}$ at $90^{\circ} \mathrm{C}$ for $20 \mathrm{~min}$, drained, and stained in $0.05 \% \mathrm{wt} / \mathrm{vol}$ trypan blue, $50 \% \mathrm{vol} / \mathrm{vol}$ glycerol, $5 \% \mathrm{vol} / \mathrm{vol}$ lactic acid, $0.05 \% \mathrm{vol} / \mathrm{vol} \mathrm{HCl}$ at $90^{\circ} \mathrm{C}$ for $2 \mathrm{~h}$. After the liquid was drained, the roots were destained overnight at room temperature in acidic glycerol $(50 \% \mathrm{vol} / \mathrm{vol}$ glycerol, $5 \% \mathrm{vol} / \mathrm{vol}$ lactic acid, $0.05 \% \mathrm{vol} / \mathrm{vol}$ $\mathrm{HCl}$ ). Mycorrhizal colonization was determined by the presence of arbuscules, vesicles, spores, or hyphae of G. intraradices using the magnified intersections method (28) on $1-\mathrm{mm}^{2}$ sections of root tissue. The magnified intersections method involved the inspection of 100 intersects between the microscope eyepiece crosshair and roots at $\times 200$ magnification. Whether the vertical eyepiece crosshair crossed one or more mycorrhizal structures was noted at each intersection. The estimate of colonization was the proportion of root length containing mycorrhizal structures.

The number of spores of $G$. intraradices contained in $5 \mathrm{~g}$ of air-dried soil was evaluated as follows (9): soil was sieved through a $250-\mu \mathrm{m}$ screen and placed in a 14-ml centrifuge tube (Sartstedt, Newton, NC) filled with deionized water. The tube was undisturbed for $15 \mathrm{~min}$ and subsequently centrifuged at $2,500 \mathrm{rpm}$ for 10 min. After the supernatant was emptied, the tube was filled with a spore extraction solution $(72 \% \mathrm{wt} / \mathrm{vol}$ sucrose, $2 \% \mathrm{wt} / \mathrm{vol}$ detergent Calgon dissolved in water) and mixed. After centrifugation for $15 \mathrm{~min}$ at 3,500 rpm to separate mycorrhizal spores from soil, the sugar layer was filtered over a $0.45-\mu \mathrm{m}$ pore Supor membrane (Gelman Sciences, Ann Arbor, MI) and Whatman no. 1 filter paper (Whatman International Ltd., Maidstone, England) combination in a vacuum-assisted funnel. Mycorrhizal spores thus collected were then examined under the dissecting microscope to determine their number per gram of soil.

Mycorrhizal colonization of grape rootings. After sterilization in a $10 \%$ sodium hypochlorite solution for $10 \mathrm{~min}$, dormant $V$. rupestris cuttings were callused in twice autoclaved moistened peat moss and perlite $(1: 1, \mathrm{vol} / \mathrm{vol})$ for 12 days at $30^{\circ} \mathrm{C}$ and $100 \%$ relative humidity. Callused cuttings were then planted in $2.5 \times$ $12.5 \mathrm{~cm}$ Ray Leach Cone-tainers (Stuewe and Sons, Corvallis, OR) filled with mycorrhizal inoculum (soil containing 15 spores/g and Sudan grass roots colonized at $50 \%$ ) or soil and nonmycorrhizal Sudan grass roots as a control. The cuttings were rooted in a growth chamber at $20^{\circ} \mathrm{C}, 80 \%$ humidity, and 12-h daylight, and watered every 3 days or as needed. Once roots reached the bottom of the pot, rootings were inoculated with the pathogen.

Pathogen infection. A representative single spore isolate (designated US40), originally isolated from grapevine in California (32), was grown on corn meal agar (Difco, BD Micro Biology Systems, Franklin Lakes, NJ) for 2 weeks. Spores were harvested into sterile water and the solution was adjusted to $10^{7}$ conidia/ml. V. rupestris rootings were inoculated individually by pouring $6 \mathrm{ml}$ of spore suspension into the pot close to the root system. Control plants were similarly supplied with $6 \mathrm{ml}$ of sterile water. The plants were grown in a growth chamber at $25^{\circ} \mathrm{C}, 65 \%$ humidity, 12-h daylight, and watered daily. Because phosphorus is known to inhibit mycorrhizal growth, its amount was reduced (but not completely suppressed) to 0.25 -strength in the Hoagland's solution (21) applied weekly.

Evaluation of disease severity, plant growth, shoot phosphorus content, and fungal colonization. Vines were lifted from the soil 8 months after inoculation with the pathogen and evaluated for disease severity, growth, percent phosphorus concentration in shoots, and mycorrhizal colonization. Leaf symptoms of individual plants were rated as the percentage of leaf area with necrosis. Root symptoms were rated using a gridline intersection method (14). Roots were randomly dispersed in a 9-cm-diameter petri plate (Fisher Scientific International) with grid lines. Through a dissecting microscope, intersections between grid lines and roots were designated as either diseased or nondiseased and were converted as the percentage of root length having lesions.

To reisolate $C$. macrodidymum from infected plants, symptomatic root lesions were surface-sterilized in a $10 \%$ sodium hypochlorite solution for $1 \mathrm{~min}$. Tissue pieces, about $2 \mathrm{~mm}$ in diameter, were removed from the lesion margins and placed on potato dextrose agar (Difco, BD Micro Biology Systems) amended with tetracycline hydrochloride $(0.01 \%)$ (SigmaAldrich, St Louis, MO). After incubation at $25^{\circ} \mathrm{C}$ for 4 days, fungi were identified as C. macrodidymum based on colony morphology and conidial characteristics.

Shoots and roots from each plant were bulked and dried at $80^{\circ} \mathrm{C}$ for $48 \mathrm{~h}$ before being weighed. Percent phosphorus concentration in shoots from each plant was determined by the University of California, Davis, Agriculture and Natural Resources Analytical Laboratory as follows: the sample was dissolved by microwave acid digestion, and ortho-phosphate $\left(\mathrm{PO}_{4}-\mathrm{P}\right)$ was extracted with a solution of $2 \%$ acetic acid. $\mathrm{PO}_{4}-\mathrm{P}$ concentration in the extract was determined spectrophotometrically at 660 $\mathrm{nm}$ by reacting with paramolybdate using an automated flow injection analyzer (35).

A representative sample of each root system was kept for estimation of mycorrhizal colonization as described above.

Statistical analysis. The experiment unit was a pot containing one plant, randomized at each level. The experiment comprised four treatments: (i) waterinoculated control, (ii) mycorrhizae alone, (iii) pathogen alone, and (iv) both mycorrhizae and pathogen. Each treatment had seven replications. The experiment was repeated twice. Leaf symptoms, root symptoms, shoot biomass, root biomass, mycorrhizal colonization, and percent phosphorus concentration in shoots data were analyzed using the GLM procedure in SAS Version 8.1 (SAS Institute, Cary, NC). The data were subjected to ShapiroWilk test for normality and Levene test for homogeneity of variance. The data fulfilled the criteria for normality and homogeneity. A preliminary analysis of the data showed no significant trial-treatment interaction; therefore, the data from the two trials were combined. A one-way analysis of variance (ANOVA) was run to analyze the effect of each treatment on leaf symptoms, root symptoms, shoot biomass, root biomass, and percent phosphorus concentration in shoots. Tukey's test was used for treatment means comparisons.

A $t$ test was used to analyze the effect of presence or absence of the pathogen on mycorrhizal colonization.

\section{RESULTS}

Pathogenicity. C. macrodidymum was reisolated from all inoculated plants (data not shown). C. macrodidymum caused leaf and root symptoms on both mycorrhizal and nonmycorrhizal plants (Table 1). When infected with the pathogen, mycorrhizal plants had significantly lower foliar symptoms, 37\% less, and root rot symptoms $40 \%$ less than nonmycorrhizal plants $(P<0.0001)$ (Table 1$)$.

Plant growth. When plants were nonmycorrhizal, plants inoculated with the pathogen developed significantly less dry shoot (50\% less) and root (30\% less) weights compared with the noninoculated plants $(P=0.0021$ and $P=0.0017$, respectively) (Table 2). 
When plants were precolonized with $G$. intraradices, dry shoot and root weights of plants inoculated with the pathogen were not significantly different from the noninoculated control (Table 2). When plants were not infected with the pathogen, the presence or absence of mycorrhizae did not significantly affect dry root or leaf weights (Table 2).

Mycorrhizal colonization. The percentage of root length colonized with $G$. intraradices was high (48.3\% for the noninoculated control and $54.5 \%$ for plants infected with $C$. macrodidymum) and not significantly affected by the presence of the pathogen $C$. macrodidymum $(P=$ 0.2256) (Table 3).

Percent phosphorus concentration in shoots. Percent phosphorus concentration in shoots of individual plants was not affected by any treatment $(0.13 \%$ for the nonmycorrhizal, noninoculated control, $0.14 \%$ for the nonmycorrhizal plants infected with $C$. macrodidymum, $0.13 \%$ for the mycorrhizal, noninoculated control, and $0.16 \%$ for the mycorrhizal plants infected with C. macrodidymum) (Table 4).

\section{DISCUSSION}

In this study, we showed that St. George (V. rupestris) rootings preinoculated with $G$. intraradices were less susceptible to $C$. macrodidymum, causal agent of black foot disease. Even though $C$. macrodidymum was consistently recovered from both mycorrhizal and nonmycorrhizal plants, disease severity was significantly lower when vines were preinoculated with $G$. intraradices. Only when plants were not mycorrhizal, grape rootings inoculated with the pathogen developed significantly less dry root and leaf weights compared with the noninoculated control.

Although the mechanisms of decreased disease susceptibility due to AM fungi are not always clear, it is often hypothesized that they result from improved nutrition of the host $(12,43)$, most commonly a better $P$ uptake $(10,15)$. In the present study, the percent phosphorus concentration in shoots of grape rootings did not significantly differ among treatments. This might be

Table 1. Influence of Cylindrocarpon macrodidymum and mycorrhizae (Glomus intraradices) on black foot symptoms on leaves and roots of grape rootings ${ }^{\mathrm{a}}$

\begin{tabular}{lcc}
\hline Treatments & $\begin{array}{c}\text { Leaf } \\
\text { symptoms } \\
(\%)\end{array}$ & $\begin{array}{c}\text { Root } \\
\text { symptoms } \\
(\%)\end{array}$ \\
\hline $\begin{array}{l}\text { Noninoculated } \\
\text { control }\end{array}$ & $0 \quad \mathrm{a}$ & $0 \mathrm{a}$ \\
C. macrodidymum & $13.75 \mathrm{c}$ & $50 \mathrm{c}$ \\
G. intraradices & $0 \quad \mathrm{a}$ & $0 \mathrm{a}$ \\
C. macrodidymum & $8.55 \mathrm{~b}$ & $30 \mathrm{~b}$ \\
$\quad$ G. intraradices & &
\end{tabular}

${ }^{\text {a }}$ Values represent means of 14 grape rootings. Means in each column followed by the same letter are not significantly different $(P=0.05)$ according to Tukey's test. because we reduced, but did not completely suppress, phosphorus in the fertilizer. The difference in growth and disease susceptibility between mycorrhizal and nonmycorrhizal plants could therefore not be explained by facilitation in phosphorus uptake. It is possible that mycorrhizal colonization improved uptake of other nutrients that we did not measure. Indeed, mycorrhizal fungi have been shown to enhance $\mathrm{N}$ uptake of grapevines (7). However, our finding of no significant differences in biomass of mycorrhizal and nonmycorrhizal plants suggests that macronutrient uptake was similar. This finding is consistent with past research on the effects of mycorrhizal colonization on infection of peach by $C$. destructans (46).

Consistent with Traquair's findings (46), we found that mycorrhizal colonization of grapevines was not significantly affected by the presence of the pathogen. Because roots were colonized with $G$. intraradices prior to inoculation with the pathogen, it is possible that very few root infection sites were available for the pathogen. It is also possible that the AM fungi on our grapevines promoted the growth of soil microbes that are antagonistic to the pathogen $(13,25)$. Results of a recent study suggest that the external hyphae associated with mycorrhizal grapevine roots are important for supporting populations of other soil microbes (X. Cheng and K. Baumgartner, in press). However, since our plants were grown in sterile soil in pots in the greenhouse, it is difficult to anticipate if soil microbes were present. Another possible explanation for the mechanism of control is induction of systemic protection, as it has been demonstrated in mycorrhizal tobacco and tomato inoculated with other root pathogens $(34,42)$.

Differences in root colonization by AM fungi have been observed between grapevine rootstocks $(3,23,26,39)$. Because these different rootstocks might respond in a number of ways to the interaction between $G$. intraradices and $C$. macrodidymum, future experiments should include different rootstocks. Because black foot disease can be caused by numerous fungi $(1,17,20,32,44)$, it is also important to

Table 2. Influence of Cylindrocarpon macrodidymum and mycorrhizae (Glomus intraradices) on growth of grape rootings ${ }^{\mathrm{a}}$

\begin{tabular}{lcc}
\hline Treatments & $\begin{array}{c}\text { Dry shoot } \\
\text { weight }(\mathbf{g})\end{array}$ & $\begin{array}{c}\text { Dry root } \\
\text { weight }(\mathrm{g})\end{array}$ \\
\hline $\begin{array}{l}\text { Noninoculated } \\
\text { control }\end{array}$ & $0.73 \mathrm{~b}$ & $0.87 \mathrm{~b}$ \\
C. macrodidymum & $0.43 \mathrm{a}$ & $0.62 \mathrm{a}$ \\
$\begin{array}{l}\text { G. intraradices } \\
\text { C. macrodidymum }\end{array}$ & $0.74 \mathrm{~b}$ & $1.02 \mathrm{~b}$ \\
+ G. intraradices & $0.61 \mathrm{~b}$ & $0.92 \mathrm{~b}$ \\
\hline
\end{tabular}

a Values represent means of 14 grape rootings. Means in each column followed by the same letter are not significantly different $(P=0.05)$ according to Tukey's test. consider the interactions of these different fungi with $G$. intraradices on a given rootstock.

Results of this study revealed the possibility of using $G$. intraradices for the management of black foot disease. Today, growers and nurseries in California do not have any effective alternatives to soil fumigation with methyl bromide for control of black foot disease or other root pathogens. Although AM fungi are generally present in vineyard soils (30), the AM fungal population composition varies according to the site. G. intraradices has been identified in California vineyards on the Central Coast (2) and only in nonfumigated sites on the North Coast (8). Individual AM fungal species or isolates might differ in their ability to control disease. Linderman and Davis (26) found that root colonization in vines inoculated with $G$. intraradices was significantly greater than with the two other AM fungal mixes (one of them being a native mix). Since precolonization with $G$. intraradices was effective under controlled conditions and we expect that native AM fungi would be the best competitors in their native soil, disease control using $G$. intraradices would be more easily achieved by inoculating the roots prior to planting. Future research will investigate possible preplant applications of $G$. intraradices to reduce black foot disease severity in nurseries and vineyards. We expect benefits from mycorrhizal inoculation, particularly in sites with a history of multiple replantings of Vitis sp.

Table 3. Influence of Cylindrocarpon macrodidymum on colonization of roots of grape rootings by Glomus intraradices ${ }^{\mathrm{a}}$

\begin{tabular}{lc}
\hline Treatments & $\begin{array}{c}\text { Root tissue } \\
\text { colonized with } \\
\text { G. intraradices } \mathbf{( \% )}\end{array}$ \\
\hline $\begin{array}{l}\text { G. intraradices } \\
\text { C. macrodidymum } \\
+ \text { G. intraradices }\end{array}$ & $48.3 \mathrm{a}$ \\
\hline
\end{tabular}

${ }^{a}$ Values represent means of 14 grape rootings. Means in each column followed by the same letter are not significantly different $(P=0.05)$ according to the $t$ test.

Table 4. Influence of Cylindrocarpon macrodidymum and Glomus intraradices on percent phosphorus concentration in shoots of grape rootings $^{\mathrm{a}}$

\begin{tabular}{lc}
\hline Treatments & $\begin{array}{c}\text { Phosphorus } \\
\text { in shoots }(\%)\end{array}$ \\
\hline Noninoculated control & $0.13 \mathrm{a}$ \\
C. macrodidymum & $0.14 \mathrm{a}$ \\
G. intraradices & $0.13 \mathrm{a}$ \\
C. macrodidymum & $0.16 \mathrm{a}$ \\
+ G. intraradices &
\end{tabular}

a Values represent means of 14 grape rootings. Means in each column followed by the same letter are not significantly different $(P=0.05)$ according to Tukey's test. 


\section{ACKNOWLEDGMENTS}

This research was supported by the California Competitive Grant Program for Research in Viticulture and Enology, the Department of Food \& Agriculture, and the California Grape Rootstock Research Foundation. We acknowledge Joe Morton (International Culture Collection of Arbuscular and Vesicular-Arbuscular Mycorrhizal fungi (INVAM), West Virginia University, WV) for providing the mycorrhizal isolate. We are grateful to Shea Jassem for her skillful assistance in reisolating Cylindrocarpon from plants. We especially thank Kendra Baumgartner (United States Department of Agriculture-Agricultural Research Service [USDA-ARS], Davis, CA) and Mike Davis (Department of Plant Pathology, University of California, Davis) for taking the time to valuably comment on this manuscript.

\section{LITERATURE CITED}

1. Armengol, J., Vincent, A., Torne, L., GarciaFigueres, F., and Garcia-Jimenez, J. 2001. Fungi associated with esca and grapevine declines in Spain: A three-year survey. Phytopathol. Mediterr. 40:S325-S329.

2. Baumgartner, K., Smith, R. F., and Bettiga, L. 2005. Weed control and cover crop management affect mycorrhizal colonization of grapevine roots and arbuscular mycorrhizal fungal spore poulations in a California vineyard. Mycorrhiza 15:111-119.

3. Bavaresco, L., and Fogher, C. 1996. Limeinduced chlorosis of grapevine as affected by rootstock and root infection with arbuscular mycorrhiza and Pseudomonas fluorescens. Vitis 35:119-123.

4. Booth, C. D. 1966. The genus Cylindrocarpon. Mycol. Pap. (CMI) 104:1-56.

5. Brayford, D. 1992. Cylindrocarpon. Pages 103-106 in: Methods for Research on Soilborne Phytopathogenic Fungi. L. L. Singleton, J. D. Michail, and C. M. Rush, eds. American Phytopathologic Society, St. Paul, MN.

6. Chakravarty, P., and Unestam, T. M. 1987. Mycorrhizal fungi prevent disease in stressed pine seedlings. J. Phytopathol. 118:335-340.

7. Cheng, X. M., and Baumgartner, K. 2004. Arbuscular mycorrhizal fungi-mediated nitrogen transfer from vineyard cover crops to grapevines. Biol. Fertility Soils 40:406-412.

8. Cheng, X., and Baumgartner, K. 2004. Survey of arbuscular mycorrhizal fungal communities in northern California vineyards and mycorrhizal colonization potential of grapevine nursery stock. HortScience 39:1702-1706.

9. Daniels, B. A., and Skipper, H. D. 1982. Methods for the recovery and quantitative estimation of propagules from soil. Pages 29-35 in: Methods and Principles of Mycorrhizal Research. N. C. Schenck, ed. American Phytopathological Society, St. Paul, MN.

10. Davis, R. M., and Menge, J. A. 1980. Influence of Glomus fasciculatus and soil phosphorus on Phytophtora root rot of citrus. Phytopathology 70:447-452.

11. Deal, D. R., Boothroy, C. W., and Mai, W. F. 1972. Replanting of vineyards and its relationship to vesicular arbuscular mycorrhizae. Phytopathology 62:172-175.

12. Dehne, H. W. 1982. Interaction between vesicular-arbuscular mycorrhizal fungi and plant pathogens. Phytopathology 72:1115-1119.

13. Filion, M., St-Arnaud, M., and Fortin, J. A. 1999. Direct interaction between the arbuscular mycorrhizal fungus Glomus intraradices and different rhizosphere microorganisms. New Phytol. 141:525-533.

14. Giovanetti, M., and Mosse, B. 1980. An evaluation of techniques for measuring vesicular-arbuscular infection in roots. New Phytol. 84:489-500.

15. Graham, J. H., and Menge, J. A. 1982. Influence of vesicular-arbuscular mycorrhizae and soil phosphorus on take-all disease of wheat. Phytopathology 72:95-98

16. Grasso, S. 1984. Infezioni di Fusarium oxysporum e di Cylindrocarpon destructans associate a una moria di giovani piante di vite in Sicilia. Inform. Fitopatol. 1:59-63.

17. Grasso, S., and Lio, G. M. 1975. Infezioni de Cylindrocarpon obtusisporum su piante di vite in Sicilian. Vitis 14:36-39.

18. Gubler, W. D., Baumgartner, K., Browne, G. T., Eskalen, A., Latham, S. R., Petit, E., and Bayramian, L. A. 2004. Root diseases of grapevines in California and their control. Aust. Plant Pathol. 33:157-165.

19. Halleen, F., Crous, P. W., and Petrini, O. 2003. Fungi associated with healthy grapevine cuttings in nurseries, with special reference to pathogens involved in the decline of young vines. Aust. Plant Pathol. 32:47-52.

20. Halleen, F., Schroers, H.-J., Groenewald, J. Z., and Crous, P. W. 2004. Novel species of Cylindrocarpon (Neonectria) and Campylocarpon gen. nov. associated with black foot disease of grapevines (Vitis spp.). Stud. Mycol. 50:431455 .

21. Hoagland, D. R., and Arnon, D. I. 1938. The water culture method for growing plant without soil. Calif. AES Bull. 347:36-39.

22. Hooker, J. E., and Black, K. E. 1995. Arbuscular mycorrhizal fungi as components of sustainable soil-plant systems. Crit. Rev. Biotechnol. 15:201-212.

23. Karagiannidis, N. D., Velemis, D., and Stavropoulos, N. 1997. Root colonization and spore population by VA-mycorrhizal fungi in four grapevine roostocks. Vitis 36:57-60.

24. Koske, R., and Gemma, J. 1989. A modified procedure for staining roots to detect mycorrhizas. Mycol. Res. 92:486-505.

25. Linderman, R. G. 1988. Mycorrhizal interactions with the rhizosphere microflora: The mycorrhizosphere effect. Phytopathology 78:366371.

26. Linderman, R. G., and Davis, E. A. 2001. Comparative response of selected grapevine rootstocks and cultivars or inoculation with different mycorrhizal fungi. Am. J. Enol. Vitic. 52:8-11.

27. Maluta, D. R., and Larignon, P. 1991. Piednoir: Mieux vaut prevenir. Viticulture 11:7172.

28. McGonigle, T. P., Miller, M. H., Evans, D. G., Fairchild, G. L., and Swan, J. A. 1990. A new method which gives an objective measure of colonization of roots by vesicular-arbuscular mycorrhizal fungi. New Phytol. 115:495-502.

29. Menge, J. A., Dunnecke, D. E., Johnson, E. L. V., and Carnes, D. W. 1978. Dosage response of the vesicular-arbuscular mycorrhizal fungi Glomus fasciculatus and $G$. constrictus to methyl bromide. Phytopathology 68:13681372.

30. Menge, J. A., Raski, D. J., Lider, L. A., Johnson, E. L. V., Jones, N. O., Kissler, J. J., and Hemstreet, C. L. 1983. Interactions between mycorrhizal fungi, soil fumigation and growth of grapes in California. Am. J.
Enol. Vitic. 34:117-121

31. Paget, D. K. 1975. The effect of Cylindrocarpon on plant growth response to vesiculararbuscular mycorrhizae. F. E. Sanders, B. Mosse and P. B. Tinker, eds. Academic Press, London.

32. Petit, E., and Gubler, W. D. 2005. Characterization of Cylindrocarpon species, the cause of black foot disease of grapevine in California. Plant Dis. 89:1051-1059.

33. Possingham, J. V., and Obbink, J. G. 1971. Endotrophic mycorrhiza and the nutrition of grapevines. Vitis 10:120-130.

34. Pozo, M. J., Cordier, C., Dumas-Gaudot, E., Gianinazzi, S., Barea, J. M., and AzconAguilar, C. 2002. Localized versus systemic effect of arbuscular mycorrhizal fungi on defence responses to Phytophthora infection in tomato plants. J. Exp. Bot. 53:525-534.

35. Prokopy, W. R. 1995. Phosphorus in acetic acid extracts. QuikChem Method 12-115-01-1 C., edited by M. Lachat Instruments, WI

36. Rego, M. C., Oliveira, H., Carvalho, A., and Phillips, A. 2000. Involvement of Phaeoacremonium spp. and Cylindrocarpon destructans with grapevine decline in Portugal. Phytopathol. Mediterr. 39:76-79.

37. Scheck, H. J., Vasquez, S. J., and Gubler, W. D. 1998. Grape growers report losses to black foot and grapevine decline. Calif. Agric. 52:19-23.

38. Scheck, H. J., Vasquez, S. J., Gubler, W. D. and Fogle, D. 1998. First report of black-foo disease, caused by Cylindrocarpon obtusisporum, of grapevine in California. Plant Dis. 82:448.

39. Schreiner, R. P. 2003. Mycorrhizal colonization of grapevine rootstocks under field conditions. Am. J. Enol. Vitic. 54:143-149.

40. Schreiner, R. P., and Bethlenfalvay, G. J. 1995. Mycorrhizal interactions in sustainable agriculture. Crit. Rev. Biotechnol. 15:271-285.

41. Schubert, A., and Cravero, M. C. 1985. Occurrence and infectivity of vesicular-arbuscular mycorrhizal fungi in north-western Italy vineyard. Vitis 24:129-138.

42. Shaul, O., Galili, S., Volpin, H., Ginzberg, I., Elad, Y., Chet, I., and Kapulnik, Y. 1999. Mycorrhiza-induced changes in disease severity and PR protein expression in tobacco leaves. Mol. Plant-Microbe Interact. 12:1000-1007.

43. Smith, G. S. 1988. The role of phosphorus nutrition in interactions of vesicular-arbuscular mycorrhizal fungi with soilborne nematodes and fungi. Phytopathology 78:371-374.

44. Sweetingham, M. 1983. Studies on the nature and pathogenicity of soilborne Cylindrocarpon spp. Ph.D. thesis. University of Tasmania, Hobart.

45. Sylvia, D. M., and Williams, S. E. 1992. Vesicular-arbuscular mycorrhizae and environmental stress. Pages 101-124 in: Mycorrhizae in Sustainable Agriculture. G. J. Bethlenfalvay and L. R. G., eds. American Society of Agronomy and Soil Science Society of America, Madison, WI.

46. Traquair, J. A. 1995. Fungal biocontrol of root diseases: Endomycorrhizal suppression of $\mathrm{Cyl}$ indrocarpon root rot. Can. J. Bot. 73(Suppl. 1):S89-S95.

47. Yuen, G. Y., Schroth, M. N., Weinhold, A. R., and Hancock, J. G. 1991. Effects of soil fumigation with methyl bromide and chloropicrin on root health and yield of strawberry. Plant Dis. $75: 416-420$. 